\title{
Ulrich Ufer*
}

\section{Globalization and Modern Identity Practices - Locals and Cosmopolitans in Seventeenth Century Amsterdam}

\begin{abstract}
This paper offers a historical analysis of cultural identification among locals and cosmopolitans in Amsterdam, the centre of the seventeenth century world system. Here, the convergence of global processes and local changes, such as increasing monetization, commodification and anonymization of everyday lives generated conditions that contributed to the formation of modern individual and group identities. Early modern globalization gave rise to a "global animus" in Amsterdam and it prompted the city's political elites to promote a cosmopolitan civic identity, expressed in allegoric art and architecture. On a theoretical level this paper criticizes objectifying or essentializing approaches to cultural globalization and to cultural identity and highlights instead the contradictions and ambiguities involved in the processes of attributing cultural meaning. A discussion of the poetry of Jacob Cats (1577-1660) reveals how local actors attributed contesting cultural meanings to the objects of global trade and how they acculturated them in different ways into their practices of local or cosmopolitan identification.
\end{abstract}

\section{Introduction}

Global systemic dynamics have been connecting and have been impacting upon localities at least ever since the early modern period and they have also played a constitutive role in bringing about the rise of modern identities. Cities in particular have been nodes of global economic exchange, of migration and of knowledge transfers. These convergences have provided advantageous conditions for the commercialized and individualized social formations of modern merchant cultures (Goody 2004). Globalization is today being described by a wide range of schol-

\footnotetext{
* Dr. Ulrich Ufer

Université de Montréal

F.A.S. Département d'Anthropologie et

Le Centre Canadien d'Études Allemandes et Européennes

Rue Jean-Brillant, Bureau 525 Montréal (Québec), Canada

ulrich.ufer@umontreal.ca

Hermes - Journal of Language and Communication Studies no 43-2009
} 
ars as a phenomenon with a long history, but it is noticeable that with a few exceptions (Gruzinski 2004; Schmidt 2001) historians have, so far, not shown much interest in the relation between globalization and local identity formation during the early modern period. The following analysis links approaches and concepts from the fields of economic and cultural history as well as from social anthropology in order to examine how the opening of a locality to global interconnectedness has impacted on identity practices and cultural change in an early modern centre of globalization. The discussion will concentrate on the example of Amsterdam, a place where global connectivity showed its impacts at a very early time in European history.

During the seventeenth century global processes aligned in Amsterdam with the rise of a local market society and the intensified movement of people, commodities and ideas across the globe altered formerly established identity practices. This paper will focus on how positive and negative value attributions to foreign commodities and the acculturation of new commodities either as "exotic" objects or their progressive "localization" contributed to the development of diverging localist and cosmopolitan identity orientations. Three case studies will serve to exemplify the tensions between these idealtypical poles of identity orientation. First, a phenomenological approach may show how a "global animus" reigned in the city of Amsterdam and how the city's magistrates forged representations of the world outside the city into a cosmopolitan civic identity. Second, an analysis of Jacob Cats' poetry dating from the early decades of the seventeenth century reveals how diverging identity orientations among localists and cosmopolitans entered into public awareness and discourse. Third, the biography of one cosmopolitan merchant of the second half of the seventeenth century, Benjamin Burlamacchi, may shed light on individual cosmopolitan identity practices. However, before this paper sets out to analyze the impact of early modern globalization on individual and group identities in Amsterdam it will be necessary to situate this approach of historical anthropology to globalization and cultural identity in the wider field of globalization studies. 


\subsection{Globalizations in History and Historiography}

Two strands of historical analysis can serve as examples of how a concern for the phenomena and structures of globalization has been part of western historiography for much longer than the recent rise of interest during the past twenty years or so. "Weltgeschichte" - World History or Universal History - on the one hand has been an ambitious project since the times of Jakob Burckhardt and has recently experienced revived attention in the context of a turn against Eurocentric grand narratives (Mazlish 1998). On the other hand, World Systems Analysis has been offering a global approach to both past and present economies and societies already since the 1970s. In fact, long before the term "globalization" became common parlance, World Systems Analysis has argued that the only valid unit for analysis in the social sciences is the global system as a whole (Wallerstein 1974, 1980).

World Systems Analysis was initially criticized for overemphasizing macro economics and the politics of hegemony at the cost of culture, but social anthropological Global Systems Analysis has added much to an understanding of how culture, politics and the economy interact under the influence of global processes (Friedman 1994, Friedman/ Ekholm-Friedman 2008; Denemark et al. 2000). This paper's study of cultural identities and globalization in early modern Amsterdam is indebted to approaches developed by World Systems Analysis and Global Systems Analysis. It thus differs decidedly from conceptualizations of culture and globalization developed by a second school of thought, whose positions have been described under the label of Globalization Analysis (Clayton 2004).

While Globalization Analysis offers an evolutionary conception of globalization which in its most glaring formulation would date back globalization's origins to no more than a few decades, the position of World Systems Analysis and Global Systems Analysis is marked by a rather systemic or structural approach to globalization. The latter implies that shifts between intensification and decline of global commodity exchange, the global concentration and dispersion of capital and a rising awareness of these phenomena among certain social strata in certain locations of the global system should be discussed deeply routed historical phenomena that may even date back five thousand years (Frank/Gills/Barry 1993). 
100

A world system as defined by World Systems Analysis does not necessarily comprise the whole terrestrial globe, but is a system of interdependences that is a world of its own, the largest expanse of which could potentially be the whole globe. Historically, world systems had for many millennia been restricted to large geographical zones characterized by independence of external connections for their systemic maintenance and reproduction. In this sense many phenomena attributed to present day globalization can be traced back to the ancient civilizational centres of West- and East-Asia, to the Roman Empire or to those of South- and Meso-America (Cioffi-Revilla 2006).

An important reorganization of the world economy, however, occurred in the sixteenth and seventeenth centuries when formerly independent or unconnected world systems in the Americas and only loosely connected world systems on the Eurasian landmass collapsed into one single world system. This unified, modern world system, then, developed distinctive characteristics. In particular, it universalized the commercialized life of formerly locally restricted merchant cultures through the emergence of capitalism as the dominant mode of production and through its global division of labour along a trichotomous (core, semiperipheral and peripheral areas) structure, that became organized within the bounds of rising nation states and via an interstate machinery. According to the groundbreaking work of Fernand Braudel (Braudel 1984) and Immanuel Wallerstein (Wallerstein 1980) the hegemonic economic centre of the seventeenth century world system was Amsterdam.

\subsection{Amsterdam in the Seventeenth Century World System}

Amsterdam became the principal city of the United Provinces of the Netherlands after their independence from Spanish rule in the late $16^{\text {th }}$ century and it very soon became the centre of an expanding capitalist world system, too. The city's geographical situation in boggy marshes but with access to maritime trade and to fishing grounds in the North Sea had always directed inhabitants' ambitions to the city's externality - i.e. to the outside world - as the origin of additional resources and profits. However, throughout the $15^{\text {th }}$ century trade had been locally restricted and in the sixteenth century only gradually reached out to encompass the grain ports of the Baltic Sea. Antwerp had traditionally exercised dominance over long distance trade in north-west Europe, but 
this situation changed drastically in 1585. Antwerp's trade was virtually annihilated over night when the city fell to Spanish occupation during the Dutch war of liberation. Offering a home to refugee merchants, Amsterdam in this way benefitted not only from their repatriated capital but also from the transfer of world spanning trade networks.

From the late sixteenth to the late seventeenth century the United Province of the Netherlands experienced an economic Golden Age through their favourable position in a European and global network of trade and finance. The country had become an important continental hub in the late sixteenth century and extended its commercial reach toward Asia and toward the Americas by setting up a financially powerful Dutch East India Company - the Vereenigde Oostindische Compagnie (VOC) - in 1602 and a West India Company twenty years later. Trade relations with Africa were established and extended during the same period. Within a European trade network the city's maritime sector served as a distributive agent for bulk goods and staple foods between places of demand and supply from the Baltic countries in the north to Spain and into the Mediterranean in the south. Through its importation of cheap raw materials the city also developed a thriving finishing industry for home consumption and export. In the global economy between Asia, Africa, America and Europe, the city's economic function was somewhat different to its role in the European trade cycle: the VOC imported a wide range of Asian luxury products - spices, porcelain, draperies, lacquered furniture, later also tea and coffee -, a variety of bulk goods and even raw materials for local finishing production like sugar, saltpetre or dyestuffs. In return, it sent out to Asia a substantive share of profits accumulated in the European trade system in the form of coined silver or bullion. Accompanying the establishment of the VOC as an early transnational corporation Amsterdam also developed the institutionalized operations of modern finance and commerce founding a national giro bank, a credit bank and a stock exchange during the first decades of the seventeenth century.

\subsection{Civic Identity and the "Global Animus" in Early Modern Amsterdam}

It is one of the crucial characteristics of cities to stand at the centre of long distance trade connections and in some sense, even medieval cit- 
ies can be said to have forecasted phenomena of present day globalization (Dutour 2004). Even an ancient metropolis like Rome cultivated a cosmopolitan atmosphere, breathing a "global animus" (Robertson/ Inglis 2006), which was constituted both by its population's capacity to "think the world" - i.e. to be conscious of the interrelations between a locality and its exteriorities - and by the representations of the wider world in the locality through the literary and visual arts, through architecture, through exotic commodities and through immigrants from strange lands. In ancient Rome, the political and ideological implications entailed in representations of global interconnectedness, or, more precisely, in the representations of empire, showed very clearly, for example, in a permanent display of a gigantic world map in the city's centre, Campus Martius (Robertson/Inglis 2006: 38).

Awareness of being connected to the wider world must not necessarily play an important role for the construction and display of a city's civic identity, but it may serve the purpose of giving expression to a new identity orientation and to a break with a heretofore rather local identity. In Amsterdam the transition from Spanish rule to autonomy in the late $16^{\text {th }}$ century had brought the rise to power of a new elite of "merchant-regents" who soon determined both domestic and foreign policy. This political and mercantile elite actively promoted the construction of a cosmopolitan civic identity, aligning it with the more popular emergence of a "global animus" in the city's quotidianal ambience. A discussion of four politically supported presentations of civic identity in the arts and in architecture may show the progressive elaboration of an allegoric language of cosmopolitan identification over the course of the seventeenth century.

In 1607, five years after the foundation of the VOC, the congregation room of the town hall of Amsterdam was decorated by a splendid harpsichord, giving new splendour to the small and somewhat unrepresentative medieval building. On its lid was painted a scene that clearly indicated the political and economic aspirations of the city's government: the vista showed a woman symbolising the city itself seated on a richly adorned throne. She posed her left hand with possessive gesture on a global sphere while holding in her right hand a cornucopia, representative of the profits she received through the connections of global trade. Around her a variety of allegorical figures represented maritime trade and in the background a mappa mundi depicted from a bird's eye view 
the American continent to the right and Asia to the left. On the middle plane, a ship set sail toward Africa and to other distant shores in search of commercial enterprise.

This initial allegoric phrasing was to provide the basic elements for future representations of Amsterdam's cosmopolitan civic identity. With rising economic fortunes and growth in global power, however, display of civic grandeur also improved and three decades later in 1638, the same allegorical theme was elaborated on the occasion of a state visit by Maria di Medici, mother of the French King Louis XIII. On the first day of her visit a play was put on scene on the waters of the harbour of Amsterdam, featuring floats with stage designs of the four continents that brought to the queen mother the riches of the world. On the second day of her visit she was invited to the headquarters of the VOC where a superlative banquet had been arranged for her, offering all the exotic importations of the company. The chronicler of her visit described in meticulous detail, how Maria di Medici savoured the tastes, colours and smells as evidences of the city's successful position in global interconnectedness.

In 1655, nearly twenty years later and at the apex of Amsterdam's economic strength, the city counsel finished building a new and more lavish town hall. The whole building was dedicated to an artful presentation of the city's civic identity, displaying wealth, rank and global standing. On the outside of the building, an alabaster relief underlined Amsterdam's claim for a central position in a world-spanning trading network. The allegory presented the city of Amsterdam centrally situated and surrounded by the four continents which offered her their wealth in resources and commodities. Inside the building, the floor of the great hall featured a marble mosaic depicting the two terrestrial and the northern celestial hemispheres. Part of the inlay was a motto taken from a poem by the celebrated poet Joost van den Vondel. Corresponding with the visual representations on the outside wall the poem left little doubt about the magistrate's global ambitions (Heeres/Bemmelen 1898: 78):

"Whosoever marks this floor and these gorgeous vaultings must think within himself: Verily, this corporation is in all its branches 


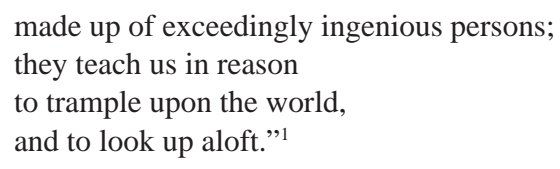

Possibly the most elaborate presentation of Amsterdam's cosmopolitan civic identity was performed in a public play of 1666 celebrating the completion of the final city extension. The ramparts had been progressively expanded over previous decades in order to house a growing population which neared the 200.000 mark at that date and made Amsterdam one of the largest European cities, second and third only to London and Paris. The play was directed by Jan Vos, an experienced stage designer and director who had gained experience in staging grand public allegorical festivals, for example, at the occasion of the end of the Thirty Years' War in 1648. Once more Amsterdam was shown as the centre of the world. Allegorically presented as a woman, the city laid claim to the riches of the world: resting her right hand on a global sphere and distributing the profits of global trade to her citizens through the mouth of a cornucopia that she held in her left hand. Again she was surrounded by the various continents that submitted their riches to her. Vos gave particular emphasis to the fact that by attaining a dominant position in world trade Amsterdam had reached a high point of evolutionary civilizational development. He described the city's current status as a Golden Age, marked not only by material wealth, but also by a proliferation of the fine arts, poetry, painting and sculpture. Amsterdam's high civilizational status as a global city was furthermore confirmed by historical comparison with the ancient civilizations of Greece and Rome which Amsterdam claimed to have surpassed in knowledge as well as in wealth and in global commercial reach.

Amsterdam's cosmopolitan civic identity, as presented by the city's political elites, shows a strong awareness of the city's relation to the world. This awareness also featured prominently in poetry and prose of the Dutch scholar Caspar Barlaeus - head of Amsterdam's newly founded university Atheneum Illustrum. In an elegy to Amsterdam's cosmopolitan civic identity he lauded the city's trade with Java, China, India

1 Original text: “Die op dit vloeren let, / En op dit heerlijk welven, / Moet zeggen bij hem selven, / Voorseker dese Wet / Bestaat in al haar leeden / Uyt hoogh vernufte Lien; / Zij leeren ons met reeden / De Wereldt te vertreeden / En opwaarts te aansien.” 
and the Moluccas and he concluded that "we Amsterdamers go [...] wherever profit will take us, to all seas and to every coast. Acquisitiveness takes us to every harbour and thus we mow and reap on widely spread out soils"” (Barlaeus 1662: 659).

Amsterdam was a global city, but not only in the sense that its elites were conscious about being linked to the whole world and thus were able "to think the world", but also in the sense that on a very quotidian level, it breathed a "global animus" inside its ramparts. Walking through the streets, contemporaries noticed the languages and looks of many different European nations, at times even of visitors coming from as far as Persia or East Asia. Some of them were part of a migrant workforce attracted by Amsterdam's sudden economic rise. Others were travelling merchants, itinerants between the different market places of the world. They brought to the street shops commodities from the four quarters of the world and besides innumerable general retailers Amsterdam counted around 30 shops specializing in East India wares during the seventeenth century. Reflecting those allegorical references to the city's global outside on the walls of the town hall, vistas of the foreign were incorporated also into more ordinary architecture. By the end of the seventeenth century, many of the stone reliefs adorning entrances to merchants' houses showed scenes from distant lands, for example a vista of the Brazilian harbour of Bahia Todos los Santos, of exotic plants like tea leaves and orange trees or of exotic animals like crocodiles. The "global animus" manifested also in at least four themed amusement houses in the city centre that attracted visitors with global spheres and mappae mundi among other curiosities. One venue advertised on pamphlets its waxwork figures, including, besides a number of European historical potentates, even a figure of the emperor "uit het machtigh Rijckdom van China" (from the mighty empire of China). In the vicinity of the headquarters of the VOC an olfactory experience of global connectedness awaited the passer-by as the stocks of pepper, cloves, nutmeg and other spices left their mark on the neighbourhood.

2 Author's translation. Original text: “wy Amsterdammers vaeren / Al waer de Ganges loost zijn wateren in zee: / Al waer de winst ons voert, na alle zeen en kusten. / Gewinzucht liet tot noch geen havens onbezocht. [...] / Aldus word d'oegst, gemaeit op wijd verspreide gronden.” 


\subsection{Globalization, Culture and Identity}

Elaborations of a cosmopolitan civic identity, a "global animus" in Amsterdam's everyday life and a growing number of foreign commodities on the markets all testify to early modern globalization's impact on the culture of the city. Conceptions of culture and of the processes of cultural change have long been controversial issues in the humanities and social sciences and they have lost nothing of their ambiguity in the context of globalization. In fact, increasing engagement with crosscultural contact in the wake of contemporary globalization has revived controversies. Particularly in social anthropology a hidden turn toward a "scientific objectification" of the culture concept has been criticized in the context of research on identities and globalization (Friedman 1994: 88). The antagonism between social anthropologists who base their investigations of cultural fluxes and cultural exchanges on the notion of an objectified concept of culture and those who understand culture as "attributed meaning" bears important implications for this historical examination of cultural globalization, too. For the sake of this discussion, the two opposing views can be contrasted as the "globalization of culture" discourse and the "global systems" discourse.

Proponents of the objectifying "globalization of culture" strand frequently refer to tropes such as the "McDonaldization" of culture (Smart 2000, Ritzer 1996), thus pointing to a perceived tendency toward global cultural homogenization. Their analyses of homogenizing flows of culture necessarily show a strong interest in questions of cultural "origins" and in the concept of hybridity. Today, such is the claim, homogenization of culture is caused less by hegemonic imposition, as used to be the case in the days of high colonialism. Rather, cultures originate in various places around the world, fluctuate on a global scale and hybridize in localities. Such a conceptualization of "flows" of cultures must necessarily start from the premise that there is both an origin and a substantial quality to culture. The concepts of origin and cultural substance are prerequisite to the idea that culture can be transferred and then mix again with other cultures on the move thus creating hybridity. Objects, according to this understanding, become carriers or containers of culture which, in fact, makes culture very similar to such physical primary qualities like size and shape that are not altered during the transfer of an object and that are hardly influenced by subjective human perception. 
By essentializing or objectifying culture, cultural difference is necessarily conceptualized as an imbedded, concrete quality of objects that can get displaced in the fluxes of global trade. Less attention is given by such conceptions to the practices by which individuals or groups attribute meaning to objects in order to establish coherence or to demarcate differences from one another (Bourdieu 1984).

Contrasting this objectifying or essentializing conception of culture, the approach taken by social-anthropological Global Systems Analysis departs from a very different conception of culture. By approaching culture as "attributed meaning", emphasis is shifted from the object as a container of fixed cultural meaning to the processes of meaning attribution at different places and under different conditions of acculturation and hence to the social actors involved in the negotiations over cultural meaning attribution. Accordingly, culture, or cultural meaning as such is not transferrable. Rather it depends on how local actors use objects in their everyday practices, for example in the processes of constructing and communicating identity. "Exotic" or strange is thus not an intrinsic quality of objects. Whether an object is "exotic" to certain local consumers is not a question of its origin, but a question of whether they acculturate the very object as exotic or whether they localize it by progressively shifting away attention from the fact that the object had once not existed in this locality.

In the United Provinces of the seventeenth century, local shifts in meaning attribution show, for example, in the progressive de-exoticization of the Japanese kimono, the first samples of which arrived in Amsterdam during the 1630s. Obtained in very limited quantity at the imperial court of Edo as presents to Dutch ambassadors the kimono initially was an exotic and exclusive garment in the Netherlands. While in Japan the kimono was a quite ordinary piece of clothing worn on the streets, in the Netherlands it was first acculturated as a luxurious dressing gown. Over the following decades, however, the kimono became part of the commercial logics of fashion waves and of copying within a market economy, and consequentially cultural meaning attribution altered in the wake. Answering to rising consumers' demands the VOC first attempted to buy more kimonos from Japan, but then from the 1680s on had kimonos produced after Japanese patterns in India by the thousand, because the cost of production was lower. At around the same time garments of East Asian designs and cuts were also printed and local- 
ly tailored in the Netherlands. Linguistically, the kimono's progressive loss of exotic connotation is mirrored by its Dutchification via "japonse rock" (Japanese gown) to the diminutive "japonnetje". As dispersion and de-exoticization of this once exotic and exclusive indoors garment continued it became a rather common students' outdoor dress in the early 1700s. Similar changes in meaning attribution occurred when Delftware producers increasingly copied Chinese porcelain. Delftware was more and more integrated into local Dutch production and consumption patterns and progressively turned into a marker of specifically Dutch identity.

\subsection{Global Market, Consumption and Modern Identities}

The development of globalized market conditions in the city of Amsterdam must be understood as part and parcel of the major economic transition from a feudalist to a capitalist mode of production and consumption during the early modern period. In this transitory phase, the Dutch economy of the seventeenth century has been described as having experienced the first wave of modern economic growth (Vries/Woude 1995). While classical economic or sociological explanations of the rise of capitalism had been focusing either on the technologies of production or on the Weberian thrift-mentalities that supported a culture of capital accumulation and reinvestment, more recent contributions have shifted attention to the importance of consumption. The origins of a consumer society have of late been studied as a phenomenon of eighteenth century England (McKendrick et al. 1982). Additionally, the work of scholars such as Charles Taylor and Colin Campbell has highlighted how the combined gradual "internalization" of the self and the "spirit of consumerism" has liberated individuals from traditional social ascription and has led to the rise of modern identities (Taylor 1989; Campbell 1987). The modern individual could nurture private identity fantasies in its inner self and express them through consumption in the context of an urban society that provided more and more niches for such identity play, especially in the developing anonymous spheres of growing metropolises.

In many ways, however, the origin of modern identities in the context of commercialized, urban social formations can be advanced to those heavily urbanized regions of the province of Holland in the seventeenth 
century, in particular to Amsterdam. Both foreign and native contemporary observers of the Dutch Golden Age, for example the Englishman Josiah Child and the Dutch politicians Johan De Witt and Pieter de la Court emphasized that growing home consumption was a decisive factor in the country's economic success story (Child 1668: 4, Witt/ Court 1746 [1666]: 32-33; Court 1911 [1659]: 8, 43, 95). The increase in wealth of Amsterdam's seventeenth century boom economy was of such extent that it affected not only a demographically restricted elite, but sustained the rise of a moderately large middle class. Roughly one third of the urban Dutch population may be counted among those whose standard of life allowed them to take an active part in the consumption of amenities and luxuries (Vries/Woude 1995: 650) and hence to express individual identity through consumption.

Besides a generally increased standard of life a number of other dynamics can be considered as contributing toward the building of a modern consumer society and to the rise of modern modes of identification in that they transformed the conditions of everyday life and eroded traditional social structures. First, the high rates of immigration - a sustained rate above $50 \%$ throughout much of the seventeenth century - disrupted the old composition of the town, gradually liberating consumption from the restraints of traditional social order and bringing new products as well as new cultural practices; second, rapid urban growth, multiplying Amsterdam's population sevenfold within the period 1580 to 1660, allowed people to experiment with different identity roles in an emerging anonymous urban sphere; finally, the fact that Amsterdam was one of the first European cities to abandon sumptuary laws reinforced tendencies toward liberal consumption. Limits to consumption were now only imposed "by the wallet" and not by social standing, as a contemporary observer poignantly put it (Ufer 2008: 184).

According to the contemporary intellectual Caspar Barlaeus Amsterdam offered its consumers an unrivalled choice of commodities and he emphasised how they contributed to the globalized and commercialized consumerist atmosphere in the city: “le Monde m'envoie ses presens, et ils sont ici exposés en vente” (Ufer 2008: 126). Traditional social restraints surely still prevailed in Amsterdam, and yet, niches of modernity opened up in everyday life where individual identity could be practiced in a commodified and monetized environment using purchasable sym- 
bols and signs. However, the cultural meaning that Amsterdam's consumers attributed to these new wares was not uncontested.

\subsection{Cosmopolitans and Locals within and without the Global City}

Different value attributions that contemporaries gave to new commodities provided by a world market and the integration of these commodities into identificatory practices soon became part of a public discourse. They have been artfully treated in a series of three poems by Jacob Cats, one of the most popular Dutch poets of the seventeenth century. All three poems - Herders Liet ("The Shepherd's Song", 1618), Harders-klacht ("The Shepherd's Lament”, 1618) and Galathea ofte Harder Minne-klachte ("Galathea, or the Shepherd's Lament over Love”, 1627 ) - date from the early decades of Dutch involvement in world trade, when the impact of new commodities on society was most strongly experienced as novel and as a break with former, more traditional patterns of consumption. All three poems feature a shepherd and a man of the town as rivals for the love of a young shepherdess or, respectively, a shepherdess and a pert young woman from the city who compete for the attention of a young shepherd. Their encounters exemplify diverging identity orientations between the country and the city, the different values attributed to foreign and local commodities and the contrasting attitudes of the different parties toward the urban money economy, or toward the rural economy of self-sufficiency. Two passages of Cats' poetry are indicative of how the use of imported or local commodities and the different means of procuring them either through self-contained labour or through a connection with the global market became part of the practices of creating local and cosmopolitan identities.

In Jacob Cats' poem Galathea ofte Harder Minne-klachte the prototypical city dweller is presented as cultivating a specifically cosmopolitan habitus. He is contrasted to a shepherd who complains over the fact that his beloved shepherdess has become the object of urban courtship. More so, the exotic presents of urban gallantry have reduced her esteem for the shepherd's customary presents, such as flowers, birds or fruit from the fields. The shepherd laments his beloved's proclivity for the more fashionable presents (Vloten 1862: 587): 


\begin{abstract}
"In esteem today things rise,
They achieve their highest price,

If they're given an exotic name,

And certainly a man must claim,

That they come from Moorish lands

Or from the barbaric strands,

That from shores in India

They've been brought here from afar.

To bad people things taste only fine

If they come from a foreign clime.”3
\end{abstract}

Acculturating commodities as "exotic" had become part of an economy of civilized affection among consumerist cosmopolitans of seventeenth century Amsterdam. However, from the perspective of the rural dweller who neither had the financial means nor the etiquette to indulge in this kind of civilized consumption, they could gain morally dubitable connotations. This negative value attribution is spelled out in Cats' poem Herders-Liet where a shepherdess makes deprecating remarks upon the conduct of a young woman who has taken up an urban lifestyle and now rivals her love for a young shepherd. Observing her competitor's distinctly "urban way" of walking, talking and dressing, she notices also the number of exotic artefacts that seem to be part of her lure. The urban woman displays in her chamber "dat vreemde blaeuwe goet" - foreign blue wares, i.e. Chinese porcelain - and this causes pejorative remarks by the shepherdess since the acceptance of gifts by suitors and a general inclination toward city life are taken as signs of social pretension and licence (Vloten 1862: 112).

As prototypical representatives of local identity practices Cats' male and female shepherds contemplate the negative aspects of city life and by consequence, they idealize country-life as an alternative and superior form of social organization. The globally connected urban markets may bless city dwellers with products from all four corners of the world and their acculturation or value attribution as exotic markers of prestige may distinguish their owners as civilized against rather boorish and unmannered locals. However, the shepherds point out that cosmopolitan

3 Author's translation. Original text: “'t Schijnt men hout'et voor bequaem, / Als het kright een vreemden naem. / 't Schijnt het krijght dan eerst sijn prijs / Als men dees en geen maeckt wijs, / Dat'et van het Mooren landt, / Of de Barbarysche strant, / Dat'et van den Indiaen, / Herwaerts komt gedreven aen: / 't Dunckt de slechte luyden best, / Wat ons geeft een vreemt gewest.” 
consumerism has traded off much of the autonomy and self-determination that is part of the rural dweller's local identity. While they describe the cosmopolitan's social and economic status as prone to the risks and fluctuations of a globally dependent inter-urban market economy, the ruralists claim to hold sway over their own conditions of life. Idealizing rural autarchy versus urban dependence on markets and the money economy, Cats' shepherds praise the virtues of the local life and the blessings that the ruralist receives through an unmediated relation to the sources of social reproduction (Vloten 1862: 584):

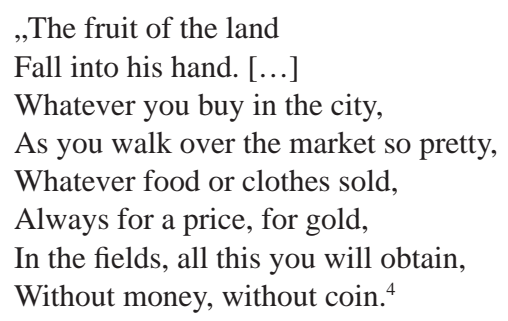

In the country, Cats' shepherds maintain, different values count than those fostered by other-dependent and morally dubious city life. The rustic claimed that the smell of sweat gave olfactory evidence to courageous virility and that callous skin was an honourable mark of rural self-sufficiency and hard labour (Vloten 1862: 584). However, just as the rural body bore witness to the physical efforts of self-contained labour, procuring the resources for existence in the immediate vicinity, so did the urban consumerist's body signal the interdependent and cosmopolitan character of the city economy into which it was embedded. Cats described his urban prototypes as perfuming their bodies with costly balms and as sweetening their breaths with exotic spices. From the cosmopolitan's perspective the civilized urban body contrasted starkly with the "boorish" - in the widest sense savage and uncivilized - body of the countryside dweller.

4 Author's translation. Original text: “Uyt de vruchten van het lant / Valt hem alles in der hant. [...] / Wat men in desteden koopt, / Als men op de marckten loopt, / Wat daer yder stelt op prijs, / 't Zy van kleedingh ofte spijs / Dat verkrijght men, op het velt, / Sonder munte, sonder gelt.” 


\subsection{An Early Modern Cosmopolitan Consumer}

The impact of global interconnectedness on cultural identity practices among cosmopolitan urbanites shows explicitly in the case of one particular individual, the merchant Benjamin Burlamacchi of the second half of the seventeenth century. By accumulating a symbolic capital of signifiers toward a global exteriority he cultivated a civilized cosmopolitan identity as a marker of social distinction. A wholesale merchant in cloth and garments Burlamacchi immigrated from Geneva to Amsterdam during the early 1660s where he took over his deceased brother's business and soon corresponded with more than 587 trade partners in 135 European cities. Some years later he had established commercial relations with merchants as distant as Batavia (present day Jakarta) and Curaçao. His letters were written in Dutch, German, Italian and French. In 1691 he was appointed by the VOC as head merchant for the branch office at Hooghly, Bengal, where he moved together with his family.

Pursuing a cosmopolitan career in the later seventeenth century Benjamin Burlamacchi was exposed to many different cultural stimuli and he as well as his family acculturated these as exotic commodities in their everyday lives. Within their private household they created an atmosphere in line with the "global animus" of the city and with clear reference to those traits which Jacob Cats described as characteristic of his cosmopolitan urban prototypes. A number of receipts from purchases for interior decoration show that the walls of the family home in one of Amsterdam's prestigious residential quarters were adorned with Japanese silks, many rooms were furnished with Chinese lacquered chests and displayed Chinese porcelain on the shelves. The Burlamacchis' bills with one of Amsterdam's finest pharmacies witness the purchase of spices and exotic perfumes. He and his wife owned both counterfeited and original Japanese kimonos as dressing gowns, while outside the home, on the streets, Mr Burlamacchi often sported an Indian rattan walking stick, as was a fashionable adornment of the urban gentlemanly body at the time.

Among cosmopolitan circles exotic commodities and signifiers to a global exteriority were connoted with a very positive cultural meaning and they were recognized as means of social distinction and as tokens of civilized manners. They signified the owner's attachment to a delocalized resource base for his social reproduction and identity consti- 
tution. Obviously Mr Burlamacchi's network comprised both global and local dimensions, but his truly cosmopolitan dissociation from any particular locality showed in a remarkable fare-well letter of 1692 at the occasion of the Burlamacchis departure for Bengal. Congratulating Benjamin Burlamacchi to the prestigious position he had achieved as a head merchant with the VOC, a friend stated that to a man like Burlamacchi it did not matter in which part of the world he lived, as long as he could lead a life of honour, reputation and contentment.

\section{Conclusion}

Identity formation in an early modern centre of world trade like Amsterdam was strongly influenced by those material and symbolic linkages that connected this locality to its global exteriority. Global connectivity with the external world - represented though art, architecture, painting, allegorical festivals and also in the composition of everyday life - inspired a "global animus" inside the city and became a point of reference for the city's cosmopolitan civic identity. Promoted by Amsterdam's new political elites after the war of liberation, the pronunciation of such a cosmopolitan civic identity may also have served as a demarcation against a formerly more traditionally articulated local civic identity.

As traditional society with its socially ascribed identities progressively gave way to the individualized urban consumerism of a global market economy, the consumer's body became a bearer of identificatory signs and symbols. In the atmosphere of Amsterdam's seventeenth century "global animus" the city's global exteriority and exotic goods were connoted with very positive cultural meanings by those who wanted to create identificatory points of reference in contrast to accustomed modes of life in the rural economy. This paper has argued against the use of the concept of the "exotic" as an objectified or essentialized cultural quality of commodities and has instead discussed notions of the "exotic" as one of the possible results of meaning attribution by particular local actors with certain aims in mind, such as the construction and expression of civilized cosmopolitan identities in contrast to traditional and localist identity orientations. From a critical stance toward global interconnectedness and cosmopolitan identities, those commodities that by some were acculturated as exotic could become part of moralizing discourses of others in which they gained negative conno- 
tations of vanity, of licence, of undue luxury consumption and of inappropriate male effeminateness. In a schematic presentation, simplified for analytical purposes, these relations can be represented as opposing ideal-types with their respective value attributions to an identificatory association with the immediate locality or with the locality's global exteriority (Figure 1).

\begin{tabular}{|l|l|l|}
\cline { 2 - 3 } \multicolumn{1}{c|}{} & global exteriority & local vicinity \\
\hline $\begin{array}{l}\text { COSMOPOLITAN } \\
\text { IDENTY }\end{array}$ & $\begin{array}{l}\text { Positive } \\
\text { (civilization, origin } \\
\text { Of wealth, site of } \\
\text { economic expansion) }\end{array}$ & $\begin{array}{l}\text { Negative } \\
\text { (backwardness, } \\
\text { savageness) }\end{array}$ \\
\hline $\begin{array}{l}\text { LOCAL } \\
\text { IDENTITY } \\
\text { ORIENTATION }\end{array}$ & $\begin{array}{l}\text { Negative } \\
\text { (interdependence, } \\
\text { origin of risk) }\end{array}$ & $\begin{array}{l}\text { Positive } \\
\text { (self-sufficiency, } \\
\text { autonomy) }\end{array}$ \\
\hline
\end{tabular}

Figure 1. Localist and Cosmopolitan Value Attribution

In more abstract terms, one of the structures underlying modern identity orientations in the commercialized urban environment of the centre of the seventeenth century world system, Amsterdam, evolved out of the variant meaning attributions to local and foreign commodities. As two contrasting prototypical identity orientations localist and cosmopolitan identities defined an opening modern identity space and they were noted and discussed by contemporaries, for example in the poetry of Jacob Cats or in the writings of the scholar Caspar Barlaeus. On the one hand, the localist's identity practices were conceived as resting on an overall avoidance of interdependence by striving for autonomy within a limited field of action and economic reach. The cosmopolitan's identity, on the other hand, was conceived as building on access to and on display of foreign commodities. As such, the cosmopolitan identity was regarded as closely related to the nexus of the global city. From an analytical point of view, the cosmopolitan identity orientation is thus decidedly modern in the sense that it was preconditioned by the commercialization of Amsterdam's society and its getting embedded into global processes of buying, selling and consuming. 


\section{Bibliography}

Barlaeus, Caspar 1662: Oratien, en Blijde inkomst van Maria de Medicis. Amsterdam: Jan van Duisbergh.

Braudel, Fernand 1984: The Perspective of the World. Volume 3 of Civilization and Capitalism. New York: Harper and Row.

Bourdieu, Pierre 1984: Distinction. A Social Critique of the Judgement of Taste. London: Routledge.

Campbell, Colin 1987: The romantic ethic and the spirit of modern consumerism. Oxford: Blackwell.

Child, Josiah 1668: Brief Observations Concerning Trade and Interest of Money. London: printed for Elizabeth Calvert at the Black-spread-Eagle in Barbican, and Henry Mortlock at the sign of the White-Heart in Westminster-Hall.

Cioffi-Revilla, Claudio 2006: The Big Collapse. A Brief Cosmology of Globalization. In Gills, Barry/Thompson, William R. (eds.), Globalization and Global History. London: Routledge, 79-95.

Clayton, Thomas 2004: “Competing Conceptions of Globalization” Revisited. Relocating the Tension between World-Systems Analysis and Globalization Analysis. In Comparative Education Review, vol. 48, no. 3, 274-294.

Court, Pieter de la 1911 [1659]: Het welvaeren der stad Leyden opgestelt in den Jahre 1659. Ed. Felix Driessen Het welvaren van Leiden. Handschrift uit het jaar 1659 's-Gravenhage: M. Nijhoff.

Denemark, Robert/Friedman, Jonathan/Gills, Barry/Modelski, George 2000: World System History: The Social Science of Long-Term Change. London: Routledge.

Dutour, Thierry 2004: La mondialisation, une aventure urbaine. Du Moyen Âge au «Globalblabla». In Vingtième Siècle. Revue d'histoire, no. 81. Jan. - Mar., 107-117.

Frank, Andre Gunde/Gills, Barry K. 1993: The world system. Five hundred years or five thousand? London: Routledge.

Friedman, Jonathan 1994: Cultural identity and Global Process. London: Sage.

Friedman, Jonathan/Ekholm-Friedman, Kajsa 2008: Modernities, Class, and the Contradictions of Globalization. The Anthropology of Global Systems. Lanham, MD: Alta Mira.

Goody, Jack 2004: Capitalism and Modernity. The Great Debate. Cambridge: Polity.

Gruzinski, Serge 2004: Les quatre parties du monde. Histoire d'une Mondialisation. Paris: Éditions de La Martinière.

Heeres, Jan/Bemmelen, Willem van 1898: Abel Janszoon Tasman's Journal of his discovery of Van Diemens Land and New Zealand in 1642. Amsterdam: Frederik Muller and Co.

Mazlish, Bruce 1998: “Comparing Global History to World History” In Journal of Interdisciplinary History, XXVIII, 3, 385-395. 
McKendrick, Neil/John Brewer/J. H. Plumb 1982. The Birth of a Consumer Society. The Commercialization of Eighteenth-Century England. Bloomington: Indiana University Press.

Ritzer, George 1996: The McDonaldization of Society. Thousand Oaks, CA: Pine Forge Press.

Robertson, Roland/Inglis, David 2006: The Global Animus. In Gills, Barry/Thompson, William R. (eds.), Globalization and Global History. London: Routledge, 33-47.

Schmidt, Benjamin 2001: Innocence Abroad. The Dutch Imagination and the New World, 1570-1670. Cambridge: Cambridge University Press.

Smart, Barry (ed.) 2000: Resisting McDonaldization. London: Sage.

Taylor, Charles 1989: Sources of the Self. The Making of Modern Identity. Cambridge, MA: Harvard University Press.

Ufer, Ulrich 2008: Welthandelszentrum Amsterdam. Globale Dynamik und modernes Leben im 17. Jahrhundert. Köln: Böhlau.

Vloten, Johannes van (ed.) 1862: Alle de wercken van Jacob Cats. Zwolle: De Erven J.J. Tijl.

Vries, Jan de/Woude, Ad van der 1995: Nederland 1500-1815. De eerste Ronde van moderne economische Groei. Amsterdam: Balans.

Wallerstein, Immanuel 1974: The Modern World-System Vol. 1, Capitalist Agriculture and the Origins of the European World-Economy in the Sixteenth Cenutry. New York: Academic Books.

Wallerstein, Immanuel 1980: The Modern World-System. Vol. 2, Mercantilism and the Consolidation of the European World-Economy. 1600-1750. New York: Academic Press.

Witt, Johan de/Court, Pieter de la 1746 [1662]: The True Interest and the Political Maxims of the Republic of Holland. London: John Campbell. 
